\title{
The time course of fish oil wash-out follows a simple dilution model in gilthead sea bream (Sparus aurata $L$.) fed graded levels of vegetable oils
}

\author{
Laura Benedito-Palos $^{\mathrm{a}}$, Juan C. Navarro ${ }^{\mathrm{a}}$, Azucena Bermejo-Nogales ${ }^{\mathrm{a}}$, Alfonso Saera-Vila ${ }^{\mathrm{a}}$, \\ Sadasivam Kaushik ${ }^{b}$ and Jaume Pérez-Sánchez ${ }^{a}{ }^{*}$
}

\footnotetext{
a Department of Biology, Culture and Pathology of Marine Species, Institute of Aquaculture Torre de la Sal (IATS, CSIC), 12595 Ribera de Cabanes, Castellón, Spain

b UMR Nutrition, Aquaculture \& Genomics, INRA, Unité-Mixte INRA-IFREMER-Univ. Bordeaux I, 64310 SaintPée-sur-Nivelle, France
}

*: Corresponding author : Jaume Pérez-Sánchez, Tel.: +34 964319500, email address : iperez@iats.csic.es

\begin{abstract}
:
The aim of the study was to determine whether changes in the tissue fatty acid (FA) profile follows a simple test dilution model after changing the dietary oil sources in gilthead sea bream. A 14-month trial was conducted with juvenile fish of $18 \mathrm{~g}$ initial body weight fed either a fish oil-based diet (FO diet) or vegetable oils replacing $33 \%$ (33VO) and $66 \%$ (66VO) of fish oil. The trial included 3 months feeding a fish oil finishing diet to follow the restoration of the FA profile with the FO diet. Fish oil replacement with/without a finishing phase of fish oil re-feeding did not affect growth and all groups reached 520 $531 \mathrm{~g}$ body weight. Changes in body composition with weight gain did not modify the FA profile of fish continuously fed FO, $33 \mathrm{VO}$ or $66 \mathrm{VO}$ diets. Increased amounts of oleic acid (18:1n-9), linoleic acid $(18: 2 n-6)$ and linolenic acid (18:3n-3), in combination with reduced proportions of $n-3$ long chain polyunsaturated FAs, were found with the partial replacement of fish oil. Hence, multivariate component analysis highlighted a gradient of fish oil load determined by the total intake of fish oil over the entire production cycle. The simple dilution model was a good descriptor of these tissue FA changes, and excellent correlations between observed and predicted values were found at the end of finishing period in fish grow out with either $33 \mathrm{VO}$ or $66 \mathrm{VO}$ diets.
\end{abstract}

Keywords: Fish; Growth; Flesh; Fatty acids; Plant proteins 


\section{Introduction}

Fish oil supplies are finite (FAO, 2006) and the continuous increase in global aquaculture production has necessitated research on alternative lipid sources for fish feeds (Watanabe, 2002). Since fish oils are also highly susceptible to contamination with persistent organic pollutants, the use of vegetable oils can contribute toward a reduction in contaminant loadings in the tissue of farmed fish (Sargent et al., 1995; Bell et al., 2005). However, vegetable oils are devoid of n-3 long chain polyunsaturated fatty acids (LC-PUFA), and can adversely affect the tissue fatty acid (FA) composition if added at high inclusion levels (Sargent and Tacon, 1999; Torstensen et al., 2005). Thus, it may be desirable to use finishing diets formulated with uncontaminated or decontaminated fish oils to restore the wild tissue FA profile of farmed fish. For instance, southern hemisphere fish oils are cleaner than northern hemisphere fish oils and can deliver similar levels of n-3 LC-PUFA at lower dietary inclusion levels (Pratoomyot et al., 2008).

Lipid tailoring is, however, a fish-specific process and marine fish show extremely low capabilities for the bioconversion of $\mathrm{C}_{18}$ polyunsaturated $\mathrm{FAs}$ into $\mathrm{C}_{20}$ and $\mathrm{C}_{22}$ PUFA (Sargent et al., 2002). Despite this, the essential FA requirements of fast growing juvenile gilthead sea bream are met in practical diets by a $25 \%$ inclusion of marine ingredients (fish meal plus fish oil) (Benedito-Palos et al., 2007). Besides, eicosapentaenoic acid (EPA, 20:5n-3) and docosahexaenoic acid (DHA, 22:6n-3) are selectively incorporated into the polar lipid fraction resulting in a high membrane phospholipid robustness (Benedito-Palos et al., 2008). The same study pointed out the fact that muscle fat depots highly reflect the composition of the diet regardless of season. Earlier studies in gilthead sea bream have also monitored the effect of fish oil 
64 re-feeding on the tissue FA profile (Izquierdo et al., 2005). In turbot and brown trout, a simple dilution model was proposed and validated by Robin et al. (2003) to follow the time-course of FA changes after shifting levels in dietary lipid sources. The same model was re-evaluated with different success in Atlantic salmon (Jobling, 2004a,b), red sea bream (Jobling, 2004a), Murray cod (Turchini et al., 2006) and Atlantic cod (Jobling et al., 2008). The rationale for the present study was to investigate whether dietary FAs are incorporated in the tissue of gilthead sea bream following similar patterns. Specifically, we monitored FA dynamics after fish oil re-feeding in fish previously fed plant proteinbased diets at two levels of fish oil replacement. Economy of fish oil usage was analysed for the entire 14-month production cycle, including both grow-out and finishing periods.

\section{Materials and methods}

2.1. Diets

Three plant protein diets with pellet size increasing $(2-5 \mathrm{~mm})$ according to fish weight were coated with vegetable oils and fish oil from the southern hemisphere to contain $53 \%$ crude protein and $21 \%$ crude lipid on a dry weight basis (Table 1 ). Fish oil was the only lipid source in the reference/finishing diet (FO). The other two diets contained a blend of vegetable oils (17:58:25 of rapeseed oil: linseed oil: palm oil), replacing 33\% (33VO) and $66 \%(66 \mathrm{VO})$ of fish oil. The fatty acid composition of diets is reported in Table 2; reduction in fish oil levels decreased the proportion of n-3 LCPUFA (predominantly EPA and DHA) from $19.4 \%$ in the FO diet to $6.6 \%$ in the $66 \mathrm{VO}$ 
89 diet. All diets were manufactured using a twin-screw extruder (Clextral, BC 45) at the

90 INRA experimental research station of Donzacq (Landes, France), dried under hot air,

91 sealed and kept in air-tight bags until use.

92

\subsection{Grow-out trial}

94

95

Juvenile gilthead sea bream (Sparus aurata L.) of Atlantic origin (Ferme Marine

de Douhet, Ile d'Oléron, France) were acclimated to laboratory conditions at the

Institute of Aquaculture Torre de la Sal (IATS) for 20 days before the start of the study.

Fish of $18 \mathrm{~g}$ initial mean body weight were distributed into 9 fibreglass tanks (3000 1) in groups of 150 fish per tank. Water flow was $20 \mathrm{l} / \mathrm{min}$, and oxygen content of outlet

100 water remained higher than $5 \mathrm{mg} / \mathrm{l}$. The growth study was undertaken over 11 months

101 (July $11^{\text {th }} 2006-$ June $\left.6^{\text {th }} 2007\right)$, and day-length and water temperature $\left(10-26^{\circ} \mathrm{C}\right)$ varied over the course of the trial following natural changes $\left(40^{\circ} 5^{\prime} \mathrm{N} ; 0^{\circ} 10^{\prime} \mathrm{E}\right)$.

104 by hand to apparent visual satiety twice a day (0900 and 1400 h, 6-7 days per week)

105 from July 2006 to September 2006, and once a day (1200 h, 4-6 days per week) from

106 October 2006 to June 2007. At regular intervals, fish were counted and group-weighed

107 under moderate anaesthesia (3-aminobenzoic acid ethyl ester, MS 222, $100 \mu \mathrm{g} / \mathrm{ml}$ )

108 (Sigma-Aldrich, Madrid, Spain). Feed distributed and mortalities ( $<5 \%$ during the

109 course of the whole 14-month period) were registered daily. 


\subsection{Fish oil finishing trial and sampling protocol}

112

113 To follow the restoration of marine FA profile in fish fed vegetable oils, two of

114 the three replicates of fish fed $33 \mathrm{VO}$ and $66 \mathrm{VO}$ diets were fed the FO diet once a day (6

115 days per week) from June 2007 to September 2007 (12 weeks). These duplicate groups

116 became $33 \mathrm{VO} / \mathrm{FO}$ and $66 \mathrm{VO} / \mathrm{FO}$, respectively. The remaining fish continued to be fed

117 with the FO (3 tanks), 33VO (1 tank) and 66VO (1 tank) diets.

118 At regular intervals after the start of the finishing diet period (zero time, 27, 55

119 and 88 days), 8 randomly selected fish per dietary treatment were killed by a blow on

120 the head. The right-hand side whole fillet (denuded from skin and bone) was excised,

121 vacuum packed and stored at $-80{ }^{\circ} \mathrm{C}$ until analyses. All procedures were carried out

122 according to institutional regulations (Consejo Superior de Investigaciones Científicas,

123 IATS Review Board) and the current European Union legislation on handling

124 experimental animals.

126 2.4. Proximate analyses

The proximate composition of diets and fillets was analysed by standard procedures (AOAC, 1990). Moisture content was determined by drying in an oven at $105^{\circ} \mathrm{C}$ for $24 \mathrm{~h}$. Subsequently, diets and fillets were freeze-dried and blended for

131 protein, lipid and ash determinations. Crude protein content $(\mathrm{N} x$ 6.25) was determined

132 in 75-100 mg samples using the automated Kjeldahl method (Kjeldahl Auto 4002430

133 Analyser, Selecta, Barcelona, Spain). Samples (0.5 g) for lipid analyses were desiccated

$134\left(105^{\circ} \mathrm{C}\right.$ for $\left.3 \mathrm{~h}\right)$ in porous recipients before Soxhlet extraction with $50 \mathrm{ml}$ diethyl ether 
at $120^{\circ} \mathrm{C}$ (Soxhlet 4001046 Auto extraction apparatus; Selecta, Barcelona, Spain). Ash content was determined after heating at $600{ }^{\circ} \mathrm{C}$ in a muffle furnace for $2 \mathrm{~h}$.

Total lipids for FA analyses were extracted by the method of Folch et al. (1957), using chloroform:methanol (2:1) containing $0.01 \%$ butylated hydroxytoluene (BHT) as antioxidant. After the addition of nonadecanoic FA (19:0) as internal standard, total lipids (TL) were subjected to acid-catalysed transmethylation for $16 \mathrm{~h}$ at $50{ }^{\circ} \mathrm{C}$ using 1

$144 \mathrm{ml}$ toluene and $2 \mathrm{ml}$ of $1 \%(\mathrm{v} / \mathrm{v})$ sulphuric acid in methanol (Christie, 1982). FA methyl 145 esters (FAME) were extracted with hexane:diethyl ether (1:1), and purified by thin layer 146 chromatography (Silica gel G 60,20 x $20 \mathrm{~cm}$ glass plates, Merck, Darmstadt, Germany) 147 using hexane:diethyl-ether:acetic acid (85:15:1.5) as a solvent system. FAME were then analyzed with a Fisons Instruments GC 8000 Series (Rodano, Italy) gas chromatograph, equipped with a fused silica $30 \mathrm{~m}$ x $0.25 \mathrm{~mm}$ open tubular column (Tracer, TR-WAX;

150 film thickness: $0.25 \mu \mathrm{m}$, Teknokroma, Spain) and a cold on-column injection system.

151 Helium was used as a carrier gas, and temperature programming was from 50 to $180{ }^{\circ} \mathrm{C}$ at $40{ }^{\circ} \mathrm{C} / \mathrm{min}$ and then to $220^{\circ} \mathrm{C}$ at $3{ }^{\circ} \mathrm{C} / \mathrm{min}$. Peaks were recorded in a personal computer using the Azur software package (version 4.0.2.0. Datalys, France). Individual

154 FAME were identified by reference to well characterized fish oil standards, and the

155 relative amount of each FA was expressed as a percentage of the total amount of FA in 156 the analysed sample. BHT and internal standard (19:0) were obtained from Sigma-Aldrich (Madrid,

158 Spain). All solvents in lipid extraction and FA analyses were HPLC grade and were 159 obtained from Merck (Darmstadt, Germany). 
Changes in the tissue FA profile as a result of fish oil re-feeding were described according to Robin et al. (2003) by the following equation:

$$
\mathrm{P}_{\mathrm{T}}=\mathrm{P}_{\mathrm{RT}}+\left[\left(\mathrm{P}_{0}-\mathrm{P}_{\mathrm{RT}}\right) /\left(\mathrm{Q}_{\mathrm{T}} / \mathrm{Q}_{0}\right)\right]
$$

165 where $\mathrm{P}_{\mathrm{T}}$ is the percentage at time $\mathrm{T}$ of a given FA, $\mathrm{P}_{0}$ is the FA percentage at the start

166 of the finishing period, and $\mathrm{P}_{\mathrm{RT}}$ is the FA percentage at time $\mathrm{T}$ in fish continuously fed

167 the reference/finishing diet. $\mathrm{Q}_{0}$ and $\mathrm{Q}_{\mathrm{T}}$ represent the initial and final (at time $\mathrm{T}$ ) tissue

168 lipid content, respectively.

169 In the present study, $\mathrm{P}_{\mathrm{T}}$ is the predicted FA percentage at a given time $\mathrm{T}$ in

170 finishing groups $(33 \mathrm{VO} / \mathrm{FO}, 66 \mathrm{VO} / \mathrm{FO}), \mathrm{P}_{0}$ is the $\mathrm{FA}$ percentage of a given $\mathrm{FA}$ at the

171 start of the finishing period in $33 \mathrm{VO}$ and $66 \mathrm{VO}$ groups, $\mathrm{P}_{\mathrm{RT}}$ represents at time $\mathrm{T}$ that of

172 the reference group always fed the finishing $\mathrm{FO}$ diet. $\mathrm{Q}_{0}$ and $\mathrm{Q}_{\mathrm{T}}$ are the initial and final

173 tissue lipid content in the respective group. The adequacy of the dilution model was

174 evaluated by direct comparisons of model predictions with the observed values.

\subsection{Statistical analysis}

Growth parameters (fish average values per tank) and the relative amount of FA were checked for normal distribution and homogeneity of variances, and when

180 necessary arcsin transformation was performed. Data were analysed by one-way

181 ANOVA followed by Student-Newman-Keuls (SNK) test at a significance level of 5\%.

182 The percentages of each FA were chemometrically analysed by multivariate principal components analysis (MPCA). All analyses were made using the SPSS package version 14.0 (SPSS Inc, Chicago, USA). 


\section{3. Results}

186

187

3.1. Growth performance

188

189 Growth, feed intake and feed conversion ratios were not affected by the dietary

190 treatment over the course of the feeding trial. Hence, at each sampling point, all data on

191 body weight and feed intake were pooled and represented in the fitting plot as the mean

192 of the 9 experimental tanks (Fig. 1B). Overall, fish grew during the 11-month grow-out

193 period from $18 \mathrm{~g}$ to $284-294 \mathrm{~g}$ with a feed efficiency (wet wt gain/dry feed intake) of

$1940.82-0.86$ over this period. The subsequent trial (3-month period) was conducted over

195 the course of summer, and the cumulative feed intake (g/fish) was of the same order of

196 magnitude as that of the initial period (324 vs $307 \mathrm{~g}$ ). At the end of the finishing diet

197 period, mean body weight of fish among tanks varied between 520 and $531 \mathrm{~g}$ with a

198 feed efficiency for the finishing period of $0.73-0.79$.

199 In absolute terms, fish oil usage ( $\mathrm{g}$ feed intake $\mathrm{x}$ ingredient percentage of fish oil

200 in the diet) in fish always fed FO, $33 \mathrm{VO}$ and $66 \mathrm{VO}$ was concordant with the percentage

201 of replacement (Fig. 2). At the end of the finishing diet period, fish oil usage in fish fed

$20233 \mathrm{VO}$ became equal to that found in the $66 \mathrm{VO} / \mathrm{FO}$ group. In the $33 \mathrm{VO} / \mathrm{FO}$ group, fish

203 oil usage was reduced by $15 \%$ in comparison to fish always fed the FO diet. 


\subsection{Lipid content and tissue FA profile}

Fillet yield and lipid content of skinned fillets was not altered by dietary

208 intervention. However, lipid deposition increased by a 20-30\% over the course of the finishing period regardless of dietary treatment (Tables 3-5).

As shown in Table 3, no consistent changes in the FA profile were found over the course of the finishing period in fish continuously fed the same diet (FO, 33VO and 66VO groups), and only a few FAs (16:1 n-7, 17:0, 18:2 n-6) showed significant differences (less than $5-30 \%$ of variation) in one or two of the three experimental groups. Regarding the effect of dietary treatment, fish fed the FO diet contained 29\% saturates (mainly 16:0 and 14:0), almost 32\% monoenes (over half of which were 18:1n-9), 1\% n-6 LC-PUFA, and 17\% n-3 LC-PUFA (predominantly EPA and DHA). Increased amounts of $18: 1 n-9,18: 2 n-6$ and 18:3n-3, in combination with reduced proportions of n-3 LC-PUFA and saturated FAs were found with the progressive replacement of fish oil by vegetable oils.

The time course of changes through the finishing period on the tissue FA profile of fish previously fed vegetable oils are shown in Tables 4 and 5. Both in 33VO/FO and 66VO/FO groups, the finishing diet caused a progressive increase in the FAs present in higher amounts in fish oil (i.e. 14:0, 16:1n-7, 20:1n-9, 22:1n-11, EPA and DHA), while those characteristic of vegetable oils (i.e. 18:1n-9, 18:2n-6 and 18:3n-3) decreased in proportion to the degree of fish oil replacement in the diet.

The MPCA analysis of fillet FA profiles before, during and at the end of the finishing period revealed that the two first components accounted for $62 \%$ of the total variation, with $52.5 \%$ of the variation being explained by component 1 itself (Fig. 3A). Some of the most characteristic variables of marine versus vegetable oils had the 
230 highest loadings on function 1 and were located at the extremes. The results of the score

231 plot are represented only for the first component since it accounted for the majority of

232 the variation (Fig. 3B). The plot revealed that the three invariable groups (FO, 33VO

233 and 66VO) were well separated from each other, with 66VO and FO at the extremes.

234 The finishing $33 \mathrm{VO} / \mathrm{FO}$ and $66 \mathrm{VO} / \mathrm{FO}$ groups were also clearly separated from each

235 other on a time- FO intake-manner (Fig. 3B). Thus, a gradient of fish oil load caused

236 either by the amount of this ingredient in the diet, or by the total intake per unit of body

237 weight, could be easily distinguishable. At the end of the finishing period, the resulting

238 FA profile of the $66 \mathrm{VO} / \mathrm{FO}$ became equal to that of fish always fed the $33 \mathrm{VO}$ diet, and

239 intermediate values between $33 \mathrm{VO}$ and $\mathrm{FO}$ groups were found for the $33 \mathrm{VO} / \mathrm{FO}$ group.

240 Regardless of nutritional background (33VO and 66VO diets), the concordance

241 between the observed FA values (x-axis) and those predicted by the dilution model (y-

242 axis) was extremely high at the end of the finishing period (Fig. 4). This gave a

243 regression line with a slope very close to $1(0.96-0.95)$ when 32 FAs were considered in

244 the models derived from both 33VO/FO and 66VO/FO fish. Similar slopes (1.04-1.05)

245 were obtained when calculations were repeated for 14 selected FAs having a high

246 weight in the MPCA.

\section{Discussion}

Data reported here, along with those of Benedito-Palos et al. (2008) over an 8month feeding trial, convincingly demonstrate that dietary fish oils of northern and southern origin can be replaced by up to $66 \%$ without negative effects on the growth performance of gilthead sea bream. These data are novel in a stenohaline marine teleost maximizing the simultaneous replacement of fish meal and fish oil by alternative plant 
255 ingredients without histopathological signs of liver and intestine damage (Benedito-

256 Palos et al., 2008). Other metabolic effects are complex, interconnected and, to date, not

257 fully understood. However, it must be noted that growth-compensatory mechanisms are

258 orchestrated at the local tissue level (skeletal muscle) by the somatotropic axis when

259 rapidly growing gilthead sea bream juveniles are fed high levels of vegetable oils

260 (Benedito-Palos et al., 2007). Besides, n-3 LC-PUFA are selectively incorporated into

261 polar lipids, and the stability of muscle phospholipid FA composition is a useful and

262 complementary criterion to assess the suitability of the replacement strategy in fish

263 feeds with low levels of marine derived ingredients (Benedito-Palos et al., 2008).

264 In fish and higher vertebrate species, neutral lipids are less conservative than

265 phospholipids (Tocher, 2003; Skalli and Robin, 2004; Schulz et al., 2005). This is

266 because they are the fat storage form and its FA profile highly reflects that of the diet. In

267 the present study, the muscle lipid content was greater than $10 \%$ on a wet matter basis,

268 and the FA profile of total lipids and thereby that of triacylglycerols (TAG) remained

269 mostly unchanged through the finishing period in fish always fed either FO, 33VO or

$27066 \mathrm{VO}$ diets. The result of these temporal series agrees with data on a previous seasonal

271 study (Benedito-Palos et al., 2008), and reinforces the idea that accelerated growth of

272 farmed fish might override most of the changes in the flesh FA profile (Grigorakis,

273 2007). However, it should be born in mind that the tissue-specific FA profile varies in

274 salmonids with the size and age of fish (Bell et al., 2002, 2003). Fish oil replacement by

275 alternative lipid sources has also a pronounced effect on the tissue FA profile of fish,

276 and we found in fish always fed $33 \mathrm{VO}$ and $66 \mathrm{VO}$ diets a $22-36 \%$ increase of $18: 1 \mathrm{n}-9$

277 and 18:2n-6 with a concurrent 20-65 \% reduction in EPA and DHA. Similar results

278 have been reported in gilthead sea bream (Izquierdo et al., 2005) and a wide variety of

279 fish species, including Atlantic salmon (Bell et al., 2002 2003b; Bransden et al., 2003; 
280 Bell, 2004; Torstensen et al., 2004; Nanton et al., 2007), rainbow trout (Drew et al., 281 2007), turbot (Regost et al., 2003), European sea bass (Montero et al., 2005; Mourente

282 and Bell, 2006), Murray cod (Francis et al., 2007a, b), red sea bream (Huang et al.,

283 2007; Piedecausa et al., 2007) and black sea bream (Peng et al., 2008). Since this feature 284 can compromise the beneficial effects of seafood (Din et al., 2004; Psota et al., 2006) as 285 the main source of EPA and DHA in the human diet, there is increased interest in finfish aquaculture for modelling the time-course of FA changes during fish oil re-feeding. Gilthead sea bream shows, in our latitude, a pronounced growth seasonality (Mingarro et al., 2002), and for the most effective restoration of EPA and DHA, the

289 finishing window should take place in the broadly active feeding period of May-

290 October. Thus, after the growth stop of winter, one month was spent before the start of 291 the finishing diet period that then was continued through the summer (June-September).

292 Several variables, including among others the growth and lipid deposition rates, need to 293 be considered when analysing the effectiveness of fish oil wash-out. Therefore, one 294 must be cautious before drawing a definitive conclusion, but the literature is prolific on 295 studies in which a complete restoration of the FA profile was not fully achieved after 296 fish oil re-feeding: 32 days in red sea bream (Glencross et al., 2003), 8 weeks in turbot 297 (Regost et al., 2003); 8 weeks in brown trout (Robin et al., 2003), 12-25 weeks in 298 Atlantic salmon (Bell et al., 2003a, b; Bell, 2004; Torstensen et al., 2004); 3 months in 299 gilthead sea bream (Izquierdo et al., 2005); 4 months in Murray cod (Turchini et al., 300 2006); and 5 months in European sea bass (Montero et al., 2005). Most evidence points 301 toward a dilution model, which was proven in turbot, brown trout and Murray cod.

302 Using original data and those derived from red sea bream (Glencross et al., 2003) and 303 Atlantic salmon (Bell et al., 2003a) studies, Jobling (2004a, b) concluded that a dilution 304 process also plays a key role in governing the muscle FA profile of these fish species. 
305 Our work in gilthead sea bream points clearly toward the same direction, and gradual 306 changes in the FA profiles of the $33 \mathrm{VO} / \mathrm{FO}$ and $66 \mathrm{VO} / \mathrm{FO}$ groups were found during the 307 finishing period, making them increasingly similar to the FO group. This is particularly

308 highlighted by the results of the MPCA that shows the gradient of fish oil load along the 309 ordinate axis.

310 Therefore, changes in the FA profile arise because the existing stores become

311 diluted as fish grow and deposit increasing amounts of dietary-derived FAs. In other

312 words, nutritional background in fish with no apparent signs of FA deficiencies has a

313 marginal role on FA turnover and tissue FA profiles, although age- and nutritional

314 condition affect the expression pattern of cytokines and key limiting enzymes on tissue

315 FA uptake and mobilization (Saera-Vila et al., 2005, 2007). Thus, using the simple

316 dilution model, a reliable FA prediction was found herein at the end of the fish oil

317 finishing period regardless of the level of fish oil replacement. The model is in fact a

318 good general descriptor of FAs, and regression curves (predicted $v s$ observed values)

319 give slopes nearby to the line of equality when either selected or almost all FAs were

320 considered in the model. In Atlantic salmon, Jobling (2004b) tested three FAs (18:1

321 isomers, 18:2 n-6 and 18:3n-3) and confirmed closely the predictions made with the

322 dilution model. Jobling (2004a) again evaluated the dilution model with data from red

323 sea bream studies (Glencross et al., 2003), and a high degree of concordance was found

324 between the predicted and observed values. However, lipid retention is a tissue and fish-

325 specific process, and probably the concordance with the dilution model will be higher in

326 species with high lipid tissues, which may explain why the predictions are better in

327 salmonids and sparid fish than in Murray cod (Turchini et al., 2006) or Atlantic cod

328 (Jobling et al., 2008). Thus, our gilthead sea bream study highlights that fish grown-out

329 with the $33 \mathrm{VO}$ diet need more than 12 weeks to revert back the FA composition toward 
330 the normal variability of fish fed fish oil-based diets. Besides, low and intermediate

331 levels of fish oil replacement can produce equally acceptable fillets when the latter is

332 accompanied by a fish oil finishing phase. This is because temporal changes on fish oil

333 intake gave a minor effect on the muscle FA profile if the absolute amount becomes

334 equal at the end of the trial. In our experimental model, this was the case for the $33 \mathrm{VO}$

335 and $66 \mathrm{VO} / \mathrm{FO}$ groups, and the tissue FA profile at the end of the 3-month finishing

336 period was very close in both groups.

337 Savings on fish oil resources are therefore limited to a simple dilution, and new

338 approaches are required to improve any mobilisation or turnover of pre-existing FAs.

339 Intake of conjugate linoleic acid complex (CLA) has a lipid-lowering effect in gilthead

340 sea bream juveniles, promotes the diversion of dietary-derived TAG from muscle and

341 adipose tissue to liver, and increase hepatic peroxisomal $\beta$ oxidation (Diez et al., 2007).

342 At the same time, however, LC-PUFA biosynthesis is reduced and changes in the

343 muscle FA profile indicate that the inclusion of CLA in aquaculture diets would be of

344 little benefit in gilthead sea bream. Nevertheless, the use of more specific

345 agonists/antagonists of peroxisome proliferator-activated receptors (PPARs) cannot be

346 excluded to improve the retention of n-3 LC-PUFA. Attention also needs to be focused

347 on the transfer from fish oil of PCBs, dioxins and other harmful lipophilic organic

348 chemicals that are now ubiquitous contaminants in the marine ecosystems (Sargent et

349 al., 1995; Jacobs et al., 2002; Bell et al., 2005; Domingo, 2007). The effects of feeding

350 strategies on toxic-kinetics will be reported separately to have a more complete

351 framework of nutritional fish tailoring, and to gain public acceptance for the fish fed

352 with alternative and sustainable diets. 


\section{Acknowledgements}

354

355 This research was funded by EU (FOOD-CT-2006-16249: Sustainable Aquafeeds to

356 Maximise the Health Benefits of Farmed Fish for Consumers, AQUAMAX) and

357 Spanish (AGL2004-06319-CO2) projects. 


\section{References}

359

360 Association of Official Analytical Chemists, 1990. Official Methods of Analysis.

361 Heldrich, K. (Ed.) AOAC, Arlington, VA, 684 pp..

362 Bell, J.G., 2004. Replacement of dietary fish oil with increasing levels of linseed oil:

363 Modification of flesh fatty acid compositions in Atlantic salmon (Salmo salar) using a

364 fish oil finishing diet. Lipids 39, 223-232.

365 Bell, J.G., Henderson, R.J., Tocher, D.R., McGhee, F., Dick, J.R., Porter, A., Smullen,

366 R.P., Sargent, J.R., 2002. Substituting fish oil with crude palm oil in the diet of Atlantic

367 salmon (Salmo salar) affects muscle fatty acid composition and hepatic fatty acid

368 metabolism. J. Nutr. 132, 222-230.

369 Bell, J.G., Tocher, D.R., Henderson, R.J., Dick, J.R., Crampton, V.O., 2003a. Altered

370 fatty acid compositions in Atlantic salmon (Salmo salar) fed diets containing linseed

371 and rapeseed oils can be partially restored by a subsequent fish oil finishing diet. J.

372 Nutr. 133, 2793-2801.

373 Bell, J.G., McGhee, F., Campbell, P.J., Sargent, J.R., 2003b. Rapeseed oil as an

374 alternative to marine fish oil in diets of post-smolt Atlantic salmon (Salmo salar):

375 changes in flesh fatty acid composition and effectiveness of subsequent fish oil "wash

376 out". Aquaculture 218, 515-528. 
377 Bell, J.G., McGhee, F., Dick, J.R., Tocher, D.R., 2005. Dioxin and dioxin-like polychlorinated biphenyls (PCBs) in Scottish farmed salmon (Salmo salar): effects of replacement of dietary marine fish oil with vegetable oils. Aquaculture 243, 305-314.

380 Benedito-Palos, L., Saera-Vila, A., Calduch-Giner, J.A., Kaushik, S., Pérez-Sánchez, J., 381 2007. Combined replacement of fish meal and oil in practical diets for fast growing 382 juveniles of gilthead sea bream (Sparus aurata L.): Networking of systemic and local 383 components of GH/IGF axis. Aquaculture 267, 199-212.

384 Benedito-Palos, L., Navarro, J.C., Sitjà-Bobadilla, A., Bell, J.G., Kaushik, S., Pérez-

385 Sánchez, J., 2008. High levels of vegetable oils in plan protein-rich diets fed to gilthead

386 sea bream (Sparus aurata L.): growth performance, muscle fatty acid profiles and

387 histological alterations of target tissues. Br. J. Nutr. 100, 992-1003.

388 Bransden, M.P., Carter, C.G., Nichols, P.D., 2003. Replacement of fish oil with 389 sunflower oil in feeds for Atlantic salmon (Salmo salar L.): effect on growth 390 performance, tissue fatty acid composition and disease resistance. Comp. Biochem.

391 Physiol. 135B, 611-625.

392 Christie,W.W., 1982. Lipid Analysis. Isolation, Separation, Identification and Structural 393 Analysis of Lipids, 2nd ed. Pergamon Press, Oxford, UK, 207 pp..

394 Diez, A., Menoyo, D., Pérez-Benavente, S., Calduch-Giner, J.A., Vega-Rubín de Celis, 395 S., Obach, A., Favre-Krey, L., Boukouvala, E., Leaver, M.J., Tocher, D.R., Pérez-

396 Sánchez, J., Krey, G., Bautista, J.M., 2007. Conjugated linoleic acid affects lipid 
397 composition, metabolism, and gene expression in gilthead sea bream (Sparus aurata L).

398 J. Nutr. 137, 1363-1369.

399 Din, J.N., Newby, D.E., Flapan, A.D., 2004. Science, medicine, and the future - Omega

4003 fatty acids and cardiovascular disease - fishing for a natural treatment. Brit. Med. J.

$401328,30-35$.

402 Domingo, J.L., 2007. Omega-3 fatty acids and the benefits of fish consumption: Is all 403 that glitters gold? Environ. Int. 33, 993-998.

404 Drew, M.D., Ogunkoya, A.E., Janz, D.M., Van Kessel, A.G., 2007. Dietary influence of 405 replacing fish meal and oil with canola protein concentrate and vegetable oils on growth 406 performance, fatty acid composition and organochlorine residues in rainbow trout 407 (Oncorhynchus mykiss). Aquaculture 267, 260-268.

408 Folch, J., Less, N., Sloane-Stanley, G.H., 1957. A simple method for insolation and 409 purification of total lipids from animal tissues. J. Biol. Chem. 226, 497-509.

410 Food and Agricultural Organisation (FAO), 2006. State of world aquaculture, FAO

411 Fisheries Technical paper ed. FAO, Rome, Italy, 134 pp..

412 Francis, D.S., Turchini, G.M., Jones, P.L., De Silva, S.S., 2007a. Effects of fish oil 413 substitution with a mix blend vegetable oil on nutrient digestibility in Murray cod, 414 Maccullochella peelii peelii. Aquaculture 269, 447-455. 
415 Francis, D.S., Turchini, G.M., Jones, P.L., De Silva, S.S., 2007b. Growth performance,

416 feed efficiency and fatty acid composition of juvenile Murray cod, Maccullochella

417 peelii peelii, fed graded levels of canola and linseed oil. Aquacult. Nutr. 13, 335-350.

418 Glencross, B.D., Hawkins, W.E., Curnow, J.G., 2003. Restoration of the fatty acid 419 composition of red seabream (Pagrus auratus) using a fish oil finishing diet after grow420 out on plant oil based diets. Aquacult. Nutr. 9, 409-418.

421 Grigorakis, K., 2007. Compositional and organoleptic quality of farmed and wild 422 gilthead sea bream (Sparus aurata) and sea bass (Dicentrarchus labrax) and factors 423 affecting it: a review. Aquaculture 272, 55-75.

424 Huang, S.S.Y., Oo, A.N., Higgs, D.A., Brauner, C.J., Satoh, S., 2007. Effect of dietary 425 canola oil level on the growth performance and fatty acid composition of juvenile red 426 sea bream, Pagrus major. Aquaculture 271, 420-431.

427 Izquierdo, M.S., Montero, D., Robaina, L., Caballero, M.J., Rosenlund, G., Ginés, R., 428 2005. Alterations in fillet fatty acid profile and flesh quality in gilthead seabream 429 (Sparus aurata) fed vegetable oils for a long term period. Recovery of fatty acid profiles 430 by fish oil feeding. Aquaculture 250, 431-444.

431 Jacobs, M.N., Covaci, A., Schepens, P., 2002. Investigation of selected persistent 432 organic pollutants in farmed Atlantic salmon (Salmo salar), salmon aquaculture feed, 433 and fish oil components of the feed. Environ. Sci. Technol. 36, 2797-2805. 
434 Jobling, M., 2004a. 'Finishing' feeds for carnivorous fish and the fatty acid dilution 435 model. Aquacult. Res. 35, 706-709.

436 Jobling, M., 2004b. Are modifications in tissue fatty acid profiles following a change in 437 diet the result of dilution?: Test of a simple dilution model. Aquaculture 232, 551-562.

438 Jobling, M., Leknes, O., Sæther, B-J, Bendiksen, E.A., 2008. Lipid and fatty acid

439 dynamics in Atlantic cod, Gadus morhua, tissues: Influence of dietary lipid 440 concentrations and feed oil sources. Aquaculture 281, 87-94.

441 Mingarro, M., Vega-Rubín de Celis, S., Astola, A., Pendón, C., Martínez Valdivia, M., 442 Pérez-Sánchez, J., 2002. Endocrine mediators of seasonal growth in gilthead sea bream 443 (Sparus aurata): the growth hormone and somatolactin paradigm. Gen. Comp. Endocr. $444128,102-111$.

445 Montero, D., Robaina, L., Caballero, M.J., Ginés, R., Izquierdo, M.S., 2005. Growth, 446 feed utilization and flesh quality of European sea bass (Dicentrarchus labrax) fed diets 447 containing vegetable oils: A time-course study on the effect of a re-feeding period with 448 a 100\% fish oil diet. Aquaculture 248, 121-134.

449 Mourente, G., Bell, J.G., 2006. Partial replacement of dietary fish oil with blends of 450 vegetable oils (rapeseed, linseed and palm oils) in diets for European sea bass 451 (Dicentrarchus labrax L.) over a long term growth study: Effects on muscle and liver 452 fatty acid composition and effectiveness of a fish oil finishing diet. Comp. Biochem. 453 Physiol. 145B, 389-399. 
454 Nanton, D.A., Vegusdal, A., Rørå, A.M.B., Ruyter, B., Baeverfjord, G., Torstensen,

455 B.E., 2007. Muscle lipid storage pattern, composition, and adipocyte distribution in 456 different parts of Atlantic salmon (Salmo salar) fed fish oil and vegetable oil.

457 Aquaculture 265, 230-243.

458 Peng, S., Chen, L., Qin, J.G., Hou, J., Yu, N., Long, Z., Ye, J., Sun, X., 2008. Effects of 459 replacement of dietary fish oil by soybean oil on growth performance and liver 460 biochemical composition in juvenile black seabream, Acanthopagrus schlegeli. 461 Aquaculture 276, 154-161.

462 Piedecausa, M.A., Mazon, M.J., Garcia Garcia, B., Hernandez, M.D., 2007. Effects of 463 total replacement of fish oil by vegetable oils in the diets of sharpsnout seabream 464 (Diplodus puntazzo). Aquaculture 263, 211-219.

465 Pratoomyot, J., Bendiksen, E.Å., Bell, J.G., Tocher, D.R., 2008. Comparison of effects 466 of vegetable oils blended with southern hemisphere fish oil and decontaminated 467 northern hemisphere fish oil on growth performance, composition and gene expression 468 in Atlantic salmon (Salmo salar L.). Aquaculture 280, 170-178.

469 Psota, T.L., Gebauer, S.K., Kris-Etherton, P., 2006. Dietary omega-3 fatty acid intake 470 and cardiovascular risk. Am. J. Cardiol. 98, 3-18.

471 Regost, C., Arzel, J., Robin, J., Rosenlund, G., Kaushik, S.J., 2003. Total replacement 472 of fish oil by soybean or linseed oil with a return to fish oil in turbot (Psetta maxima): 1.

473 Growth performance, flesh fatty acid profile, and lipid metabolism. Aquaculture 217, $474 \quad 465-482$. 
475 Robin, J.H., Regost, C., Arzel, J., Kaushik, S.J., 2003. Fatty acid profile of fish

476 following a change in dietary fatty acid source: model of fatty acid composition with a 477 dilution hypothesis. Aquaculture 225, 283-293.

478 Saera-Vila, A., Calduch-Giner, J.A., Gómez-Requeni, P., Médale, F., Kaushik, S., 479 Pérez-Sánchez, J., 2005. Molecular characterization of gilthead sea bream (Sparus 480 aurata) lipoprotein lipase. Transcriptional regulation by season and nutritional 481 condition in skeletal muscle and fat storage tissues. Comp. Biochem. Physiol. 142B, $482 \quad 224-232$.

483 Saera-Vila, A., Calduch-Giner, J.A., Navarro, I., Pérez-Sánchez, J., 2007. Tumour 484 necrosis factor (TNF) $\alpha$ as a regulator of fat tissue mass in the Mediterranean gilthead 485 sea bream (Sparus aurata L.). Comp. Biochem. Physiol. 146B, 338-345.

486 Sargent, J.R., Tacon, A.G.J., 1999. Development of farmed fish: a nutritionally 487 necessary alternative to meat. Proc. Nutr. Soc. 58, 377-383.

488 Sargent, J.R., Bell, J.G., Bell, M.V., Henderson, R.J., Tocher, D.R., 1995. Requirement 489 criteria for essential fatty acids. J. Appl. Ichthyol. 11, 183-198.

490 Sargent, J., Tocher, D.R., Bell, J.G., 2002. The lipids. In: Halver, J.E., Hardy, R.W. 491 (Eds.), Fish Nutrition. Academic Press, San Diego, CA, pp. 181-257.

492 Schulz, C., Knaus, U., Wirth, M., Rennert, B., 2005. Effects of varying dietary fatty 493 acid profile on growth performance, fatty acid, body and tissue composition of juvenile 494 pike perch (Sander lucioperca). Aquacult. Nutr. 11, 403-413. 
495 Skalli, A., Robin, J.H., 2004. Requirement of n-3 long chain polyunsaturated fatty acids

496 for European sea bass (Dicentrarchus labrax) juveniles: growth and fatty acid

497 composition. Aquaculture 240, 399-415.

498 Tocher, D.R., 2003. Metabolism and functions of lipids and fatty acids in teleost fish.

499 Rev. Fish. Sci. 11, 107-184.

500 Torstensen, B.E., Froyland, L., Ørnsrud, R., Lie, Ø., 2004. Tailoring of a

501 cardioprotective muscle fatty acid composition of Atlantic salmon (Salmo salar) fed

502 vegetable oils. Food Chem. 87, 567-580.

503 Torstensen, B.E., Bell, J.G., Roselund, G., Henderson, R.J., Graff, I.E., Tocher, D.R.,

504 Lie, Ø., Sargent, J.R., 2005. Tailoring of Atlantic salmon (Salmo salar L.) flesh lipid

505 composition and sensory quality by replacing fish oil with a vegetable oil blend. J. Agr.

506 Food Chem. 53, 10166-10178.

507 Turchini, G.M., Francis, D.S., De Silva, S.S., 2006. Modification of tissue fatty acid

508 composition in Murray cod (Maccullochella peelii peelii, Mitchell) resulting from a

509 shift from vegetable oil diets to a fish oil diet. Aquacult. Res. 37, 570-585.

510 Watanabe, T., 2002. Strategies for further development of aquatic feeds. Fisheries Sci.

$51168,242-252$.

512

513

514 


\section{Legends}

516

517 Figure 1. (A) Seasonal changes on temperature (solid line) and day length (dashed line).

518 White and black boxes at the top of figure refer to summer and winter period,

519 respectively. (B) Body weight representation as mean \pm SEM of all experimental groups

520 in the experimental design. Arrows indicate the start of the study and finishing periods.

521 Cumulative feed intake is indicated at the top of figure for each period.

522

523 Figure 2. Effects of diet composition and feeding protocol on fish oil intake (g feed

524 intake $\mathrm{x}$ ingredient percentage of fish oil in the diet) per fish through grow-out (330

525 days, black bars) and finishing (88 days, grey bars) periods.

526

527 Figure 3. Component plot (A) and factor score plot (B) of the MPCA for the fillet FA

528 profile through the 3-month finishing period (June-September). Temporal series (July,

529 August and September) derived from 33VO/FO and 66VO/FO fish are represented in

530 factor score 1 as mean $\pm \operatorname{SEM}(n=8)$. No temporal changes were found for FO, 33VO

531 and 66VO groups and data from June and September (initial and final steps of finishing

532 period) are represented as one point for each group.

533

534 Figure 4. Plot prediction (dilution model) in 33VO/FO (A) and 66VO/FO (B) groups of

535 the tissue FA profile at the end of the finishing period. Observed values are the mean \pm

536 SEM of 8 fish per treatment. The solid line is the plotted regression. The equations were

537 calculated considering both the selected and all (square brackets) the identified FAs. 
539 Table 1. Ingredients and chemical composition of the experimental diets.

\begin{tabular}{|c|c|c|c|}
\hline Ingredient (\%) & FO & $33 \mathrm{VO}$ & $66 \mathrm{VO}$ \\
\hline Fish meal (CP 70\%) $^{1}$ & 15 & 15 & 15 \\
\hline CPSP $90^{2}$ & 5 & 5 & 5 \\
\hline Corn gluten & 40 & 40 & 40 \\
\hline Soybean meal & 14.3 & 14.3 & 14.3 \\
\hline Extruded wheat & 4 & 4 & 4 \\
\hline Fish oil ${ }^{3}$ & 15.15 & 10.15 & 5.15 \\
\hline Rapeseed oil & 0 & 0.85 & 1.7 \\
\hline Linseed oil & 0 & 2.9 & 5.8 \\
\hline Palm oil & 0 & 1.25 & 2.5 \\
\hline Soya lecithin & 1 & 1 & 1 \\
\hline Binder & 1 & 1 & 1 \\
\hline Mineral premix $^{4}$ & 1 & 1 & 1 \\
\hline Vitamin premix ${ }^{5}$ & 1 & 1 & 1 \\
\hline $\mathrm{CaHPO}_{4} \cdot 2 \mathrm{H}_{2} \mathrm{O}(18 \% \mathrm{P})$ & 2 & 2 & 2 \\
\hline L-Lys & 0.55 & 0.55 & 0.55 \\
\hline
\end{tabular}

Proximate composition

Dry matter (DM, \%)

92.9

92.77

Crude protein $(\% \mathrm{DM})$

53.2

52.81

52.62

Crude fat $(\% \mathrm{DM})$

21.09

20.99

540 Ash (\% DM)

$541{ }^{1}$ Fish meal (Scandinavian LT)

$542 \quad{ }^{2}$ Fish soluble protein concentrate (Sopropêche, France)

$543{ }^{3}$ Fish oil (Sopropêche, France)

$544{ }^{4}$ Supplied the following ( $\mathrm{mg} / \mathrm{kg}$ diet, except as noted): calcium

545 carbonate $(40 \% \mathrm{Ca}) 2.15 \mathrm{~g}$, magnesium hydroxide $(60 \% \mathrm{Mg})$

$5461.24 \mathrm{~g}$, potassium chloride $0.9 \mathrm{~g}$, ferric citrate $0.2 \mathrm{~g}$, potassium

547 iodine $4 \mathrm{mg}$, sodium chloride $0.4 \mathrm{~g}$, calcium hydrogen phosphate

$54850 \mathrm{~g}$, copper sulphate 0.3 , zinc sulphate 40 , cobalt sulphate 2 ,

549 manganese sulphate 30 , sodium selenite 0.3 .

$550{ }^{5}$ Supplied the following $(\mathrm{mg} / \mathrm{kg}$ diet $)$ : retinyl acetate 2.58 , DL-

551 cholecalciferol 0.037 , DL- $\alpha$ tocopheryl acetate 30 , menadione

552 sodium bisulphite 2.5 , thiamin 7.5 , riboflavin 15 , pyridoxine 7.5 ,

553 nicotinic acid 87.5, folic acid 2.5, calcium pantothenate 2.5,

554 vitamin $\mathrm{B}_{12} 0.025$, ascorbic acid 250, inositol 500, biotin 1.25

555 and choline chloride 500. 
557 Table 2. FA composition of the experimental diets ( $\%$ of total FAME).

558

\begin{tabular}{|c|c|c|c|}
\hline FA $\%$ & $\mathrm{FO}$ & $33 \mathrm{VO}$ & $66 \mathrm{VO}$ \\
\hline $14: 0$ & 7.18 & 5 & 2.7 \\
\hline $15: 0$ & 0.12 & 0.09 & $\operatorname{tr}$ \\
\hline $16: 0$ & 22.26 & 20.30 & 18.48 \\
\hline $16: 1 n-7$ & 7.06 & 4.85 & 2.62 \\
\hline $16: 2$ & 0.47 & 0.31 & 0.15 \\
\hline $16: 3$ & 1.66 & 1.09 & 0.46 \\
\hline $16: 3 n-3$ & 0.11 & 0.07 & 0.03 \\
\hline $16: 4$ & 1.8 & 1.1 & 0.47 \\
\hline $17: 0$ & 0.96 & 0.64 & 0.32 \\
\hline $18: 0$ & 4.27 & 3.92 & 3.55 \\
\hline $18: \ln -9$ & 12.49 & 20.39 & 24.59 \\
\hline $18: 1 n-7$ & 2.97 & 0.23 & $\operatorname{tr}$ \\
\hline $18: 2 n-6$ & 10.35 & 14.03 & 17.48 \\
\hline $18: 3 n-6$ & 0.34 & 0.21 & 0.09 \\
\hline $18: 3 n-3$ & 0.81 & 9.16 & 17.33 \\
\hline $18: 4 n-3$ & 1.8 & 1.17 & 0.62 \\
\hline $20: 0$ & 0.07 & 0.07 & 0.06 \\
\hline $20: 1 n-9$ & 0.92 & 0.97 & 1.03 \\
\hline $20: 2 n-6$ & 0.6 & 0.16 & 0.19 \\
\hline $20: 3 n-6$ & 0.07 & 0.11 & $\operatorname{tr}$ \\
\hline $20: 4 n-6$ & 0.69 & 0.43 & 0.18 \\
\hline $20: 4 n-3$ & 0.3 & 0.21 & 0.15 \\
\hline $20: 5 n-3$ & 13.57 & 8.84 & 4.38 \\
\hline $22: 1 n-11$ & 0.97 & 0.82 & 0.76 \\
\hline $22: 5 n-3$ & 0.81 & 0.56 & 0.23 \\
\hline $22: 6 n-3$ & 4.78 & 3.3 & 1.88 \\
\hline Total & 97.83 & 98.25 & 97.81 \\
\hline Saturates & 34.86 & 30.02 & 25.11 \\
\hline Monoenes & 24.41 & 27.26 & 29 \\
\hline n-3 LC-PUFA ${ }^{1}$ & 19.46 & 12.91 & 6.64 \\
\hline n-6 LC-PUFA ${ }^{2}$ & 1.36 & 0.7 & 0.37 \\
\hline
\end{tabular}

$559 \operatorname{tr}=$ trace values

$560{ }^{1}$ Calculated excluding $16 \mathrm{C}$ and $18 \mathrm{C}$.

$561{ }^{2}$ Calculated excluding $18 \mathrm{C}$. 
562 Table 3. Fillet weight, wet lipid content and FA profile (\% of total FAME) in fish always fed 563 FO, 33VO and 66VO diets. Fish were sampled at the beginning (June 2007) and at the end of 564 the finishing period (September 2007). Mean values and standard deviations of individual fish 565 are presented $(\mathrm{n}=8)$. Mean values within dietary groups with unlike superscript letters are 566 significantly different $(\mathrm{P}<0.05)$.

\begin{tabular}{|c|c|c|c|c|c|c|c|c|c|c|c|c|}
\hline & \multicolumn{4}{|c|}{$\mathrm{FO}$} & \multicolumn{4}{|c|}{$33 \mathrm{VO}$} & \multicolumn{4}{|c|}{$66 \mathrm{VO}$} \\
\hline & \multicolumn{2}{|c|}{ June } & \multicolumn{2}{|c|}{ September } & \multicolumn{2}{|c|}{ June } & \multicolumn{2}{|c|}{ September } & \multicolumn{2}{|c|}{ June } & \multicolumn{2}{|c|}{ September } \\
\hline & Mean & $\mathrm{SD}$ & Mean & SD & Mean & $\mathrm{SD}$ & Mean & SD & Mean & $\mathrm{SD}$ & Mean & SD \\
\hline Fillet (g) & $61.50^{\mathrm{a}}$ & 12.5 & $114.7^{b}$ & 14.4 & $59.52^{\mathrm{a}}$ & 5.73 & $113.1^{b}$ & 20.5 & $58.23^{\mathrm{a}}$ & 13.2 & $124.2^{b}$ & 14.9 \\
\hline Lipid (\%) & $9.19^{\mathrm{a}}$ & 2.01 & $11.36^{\mathrm{b}}$ & 1.21 & $10.97^{\mathrm{a}}$ & 3.20 & $12.84^{\mathrm{b}}$ & 3.24 & $9.33^{\mathrm{a}}$ & 2.02 & $11.40^{\mathrm{b}}$ & 0.88 \\
\hline$\Sigma$ FAs (mg/g) & 53.99 & 6.61 & 61.67 & 10.8 & 62.46 & 18.8 & 66.78 & 16.5 & 59.76 & 14.2 & 60.54 & 7.86 \\
\hline \multicolumn{13}{|l|}{ FA $(\%)$} \\
\hline $14: 0$ & 5.34 & 0.47 & 5.72 & 0.51 & 4.24 & 0.52 & 4.21 & 0.43 & 2.78 & 0.32 & 2.92 & 0.42 \\
\hline $15: 0$ & 0.20 & 0.09 & 0.17 & 0.05 & 0.27 & 0.14 & 0.19 & 0.08 & 0.27 & 0.22 & 0.21 & 0.18 \\
\hline $16: 0$ & 17.78 & 1.37 & 19.34 & 0.51 & 17.62 & 0.70 & 18.65 & 0.99 & 16.58 & 0.36 & 18.00 & 0.68 \\
\hline $16: 1 n-7$ & 7.96 & 0.64 & 8.36 & 0.25 & 5.96 & 0.47 & 5.94 & 0.18 & $3.85^{\mathrm{a}}$ & 0.14 & $4.08^{\mathrm{b}}$ & 0.17 \\
\hline $16: 2$ & 1.03 & 0.20 & 0.90 & 0.29 & 0.60 & 0.10 & 0.69 & 0.15 & 0.27 & 0.09 & 0.35 & 0.08 \\
\hline $16: 3$ & 1.21 & 0.21 & 1.35 & 0.06 & 0.82 & 0.08 & 0.91 & 0.17 & 0.43 & 0.23 & 0.55 & 0.14 \\
\hline $16: 4$ & 1.09 & 0.30 & 0.95 & 0.08 & 0.52 & 0.06 & 0.53 & 0.07 & 0.24 & 0.02 & 0.26 & 0.02 \\
\hline $17: 0$ & $0.66^{\mathrm{a}}$ & 0.31 & $0.45^{\mathrm{b}}$ & 0.37 & 0.24 & 0.02 & 0.25 & 0.01 & 0.25 & 0.09 & 0.25 & 0.14 \\
\hline 18:0 & 3.70 & 0.38 & 3.71 & 0.30 & 3.76 & 0.17 & 3.90 & 0.19 & 3.85 & 0.12 & 3.84 & 0.12 \\
\hline $18: 1 \mathrm{n}-9$ & 18.13 & 2.24 & 18.11 & 0.77 & 23.21 & 1.05 & 23.27 & 0.59 & 27.06 & 0.71 & 26.97 & 0.59 \\
\hline $18: 1 \mathrm{n}-7$ & 3.23 & 0.25 & 3.30 & 0.14 & 2.56 & 0.12 & 2.52 & 0.10 & 2.00 & 0.12 & 1.98 & 0.19 \\
\hline $18: 2 n-6$ & $9.39^{\mathrm{a}}$ & 0.83 & $8.95^{\mathrm{b}}$ & 0.31 & $12.32^{\mathrm{a}}$ & 0.75 & $11.96^{\mathrm{b}}$ & 0.55 & 15.02 & 0.31 & 14.34 & 0.31 \\
\hline $18: 3 n-6$ & 0.38 & 0.06 & 0.39 & 0.02 & 0.25 & 0.02 & 0.25 & 0.01 & 0.14 & 0.01 & 0.15 & 0.03 \\
\hline $18: 3 n-3$ & 1.16 & 1.20 & 0.71 & 0.04 & 7.39 & 0.93 & 7.11 & 0.26 & 12.94 & 0.33 & 10.82 & 4.33 \\
\hline $18: 4 n-3$ & 1.16 & 0.14 & 1.23 & 0.07 & 0.82 & 0.02 & 0.82 & 0.05 & 0.60 & 0.06 & 2.03 & 4.07 \\
\hline 20:0 & 0.20 & 0.02 & 0.20 & 0.01 & 0.19 & 0.01 & 0.22 & 0.06 & 0.18 & 0.02 & 0.19 & 0.01 \\
\hline $20: 1 \mathrm{n}-7$ & 0.21 & 0.02 & 0.22 & 0.01 & 0.15 & 0.01 & 0.16 & 0.01 & 0.11 & 0.01 & 0.11 & 0.01 \\
\hline $20: 1 \mathrm{n}-9$ & 1.14 & 0.08 & 1.21 & 0.02 & 1.02 & 0.05 & 1.08 & 0.03 & 0.96 & 0.03 & 1.02 & 0.03 \\
\hline $20: 1 n-11$ & 0.24 & 0.02 & 0.24 & 0.02 & 0.20 & 0.02 & 0.20 & 0.02 & 0.17 & 0.02 & 0.17 & 0.01 \\
\hline $20: 2 n-6$ & 0.25 & 0.08 & 0.26 & 0.04 & 0.28 & 0.06 & 0.29 & 0.05 & 0.32 & 0.07 & 0.32 & 0.07 \\
\hline $20: 3 n-6$ & 0.26 & 0.07 & 0.28 & 0.03 & 0.23 & 0.04 & 0.25 & 0.07 & 0.24 & 0.11 & 0.21 & 0.06 \\
\hline $20: 3 n-3$ & 0.16 & 0.20 & 0.23 & 0.25 & 0.23 & 0.09 & 0.26 & 0.09 & 0.34 & 0.04 & 0.36 & 0.05 \\
\hline $20: 4 n-6$ & 0.57 & 0.18 & 0.53 & 0.19 & 0.40 & 0.12 & 0.36 & 0.09 & 0.23 & 0.03 & 0.24 & 0.03 \\
\hline $20: 4 n-3$ & 0.61 & 0.06 & 0.62 & 0.03 & 0.51 & 0.03 & 0.51 & 0.03 & 0.42 & 0.02 & 0.40 & 0.03 \\
\hline $20: 5 n-3$ & 8.49 & 0.89 & 8.84 & 0.36 & 5.57 & 0.39 & 5.25 & 0.38 & 2.88 & 0.18 & 2.98 & 0.31 \\
\hline $22: 0$ & 0.17 & 0.06 & 0.16 & 0.06 & 0.16 & 0.06 & 0.15 & 0.05 & 0.14 & 0.03 & 0.15 & 0.03 \\
\hline $22: 1 \mathrm{n}-9$ & 0.32 & 0.02 & 0.32 & 0.03 & 0.31 & 0.02 & 0.30 & 0.02 & 0.29 & 0.01 & 0.28 & 0.02 \\
\hline $22: 1 \mathrm{n}-11$ & 0.89 & 0.06 & 0.95 & 0.03 & 0.72 & 0.05 & 0.73 & 0.05 & 0.58 & 0.01 & 0.59 & 0.02 \\
\hline $22: 5 n-3$ & 2.66 & 0.33 & 2.63 & 0.15 & 1.92 & 0.12 & 1.94 & 0.19 & 1.19 & 0.04 & 1.20 & 0.17 \\
\hline $22: 6 n-3$ & 5.48 & 0.90 & 5.16 & 0.20 & 3.92 & 0.21 & 3.58 & 0.27 & 2.57 & 0.21 & 2.29 & 0.18 \\
\hline $24: 1 \mathrm{n}-9$ & 0.35 & 0.06 & 0.28 & 0.11 & 0.31 & 0.03 & 0.26 & 0.11 & 0.31 & 0.04 & 0.30 & 0.03 \\
\hline Saturates & 28.04 & 1.92 & 29.75 & 0.74 & 26.47 & 1.64 & 27.26 & 1.29 & 24.04 & 0.67 & 25.56 & 0.90 \\
\hline Monoenes & 32.53 & 2.58 & 33.22 & 0.84 & 34.45 & 1.81 & 34.51 & 0.64 & 35.18 & 0.84 & 35.32 & 0.73 \\
\hline n-3 LC-PUFA ${ }^{1}$ & 17.40 & 2.06 & 17.47 & 0.60 & 12.15 & 0.84 & 11.54 & 0.76 & 7.40 & 0.22 & 7.23 & 0.62 \\
\hline n-6 LC-PUFA ${ }^{2}$ & 1.09 & 0.21 & 1.07 & 0.18 & 0.92 & 0.22 & 0.90 & 0.09 & 0.79 & 0.06 & 0.78 & 0.06 \\
\hline
\end{tabular}

${ }^{1}$ Calculated excluding $18 \mathrm{C} .{ }^{2}$ Calculated excluding $18 \mathrm{C}$. 
567 Table 4. Effects of finishing diet on fillet weight, wet lipid content and FA profile (\% of total

568 FAME) in fish fed $33 \mathrm{VO}$ diet and then FO diet (33VO/FO group). Fish were sequentially

569 sampled through the finishing period (June, +0; July, +27; August, +55; September, +88).

570 Mean values and standard deviations of individual fish are presented $(\mathrm{n}=8)$. Raw values with

571 unlike superscript letters are significantly different over sampling time $(\mathrm{P}<0.05)$.

\begin{tabular}{|c|c|c|c|c|c|c|c|c|}
\hline & \multicolumn{2}{|c|}{ Jun $(+0)$} & \multicolumn{2}{|c|}{ Jul (+27) } & \multicolumn{2}{|c|}{$\operatorname{Aug}(+55)$} & \multicolumn{2}{|c|}{ Sep $(+88)$} \\
\hline & Mean & SD & Mean & SD & Mean & $\mathrm{SD}$ & Mean & $\mathrm{SD}$ \\
\hline Fillet (g) & $59.52^{\mathrm{a}}$ & 5.73 & $74.58^{\mathrm{b}}$ & 14.8 & $98.66^{\mathrm{c}}$ & 8.59 & $126.1^{d}$ & 12.5 \\
\hline Lipid (\%) & 10.97 & 3.20 & 11.44 & 1.82 & 13.19 & 1.73 & 12.36 & 1.62 \\
\hline$\Sigma$ FAs $(\mathrm{mg} / \mathrm{g})$ & 62.46 & 18.8 & 68.26 & 23.5 & 69.64 & 12.6 & 63.84 & 19.9 \\
\hline FA $(\%)$ & & & & & & & & \\
\hline $14: 0$ & $4.24^{\mathrm{a}}$ & 0.52 & $4.39^{\mathrm{ab}}$ & 0.36 & $4.55^{\mathrm{ab}}$ & 0.35 & $4.98^{\mathrm{b}}$ & 0.32 \\
\hline $15: 0$ & 0.27 & 0.14 & 0.17 & 0.08 & 0.17 & 0.07 & 0.15 & 0.08 \\
\hline $16: 0$ & $17.62^{\mathrm{a}}$ & 0.70 & $18.29^{b}$ & 0.40 & $18.77^{\mathrm{b}}$ & 0.52 & $19.30^{\mathrm{b}}$ & 0.36 \\
\hline $16: \ln -7$ & $5.96^{\mathrm{a}}$ & 0.47 & $6.48^{\mathrm{ab}}$ & 0.20 & $6.97^{\mathrm{b}}$ & 0.32 & $7.15^{\mathrm{b}}$ & 0.12 \\
\hline $16: 2$ & $0.60^{\mathrm{a}}$ & 0.10 & $0.78^{\mathrm{b}}$ & 0.14 & $0.74^{\mathrm{b}}$ & 0.25 & $0.72^{\mathrm{b}}$ & 0.22 \\
\hline $16: 3$ & $0.82^{\mathrm{a}}$ & 0.08 & $0.94^{\mathrm{ab}}$ & 0.07 & $1.01^{\mathrm{b}}$ & 0.06 & $1.08^{\mathrm{b}}$ & 0.10 \\
\hline $16: 4$ & $0.52^{\mathrm{a}}$ & 0.06 & $0.55^{\mathrm{ab}}$ & 0.24 & $0.62^{\mathrm{ab}}$ & 0.21 & $0.71^{\mathrm{b}}$ & 0.12 \\
\hline $17: 0$ & 0.24 & 0.02 & 0.26 & 0.03 & 0.40 & 0.28 & 0.30 & 0.05 \\
\hline $18: 0$ & 3.76 & 0.17 & 3.89 & 0.08 & 3.70 & 0.18 & 3.93 & 0.10 \\
\hline $18: 1 \mathrm{n}-9$ & $23.21^{\mathrm{a}}$ & 1.05 & $22.61^{\mathrm{ab}}$ & 0.98 & $21.84^{\mathrm{ab}}$ & 0.88 & $21.58^{\mathrm{b}}$ & 0.78 \\
\hline $18: 1 \mathrm{n}-7$ & $2.56^{\mathrm{a}}$ & 0.12 & $2.75^{\mathrm{b}}$ & 0.12 & $2.89^{\mathrm{bc}}$ & 0.14 & $2.94^{\mathrm{c}}$ & 0.12 \\
\hline $18: 2 n-6$ & $12.32^{\mathrm{a}}$ & 0.75 & $11.61^{\mathrm{b}}$ & 0.60 & $10.77^{\mathrm{c}}$ & 0.29 & $10.16^{\mathrm{d}}$ & 0.17 \\
\hline $18: 3 n-6$ & $0.25^{\mathrm{a}}$ & 0.02 & $0.29^{\mathrm{b}}$ & 0.01 & $0.31^{\mathrm{c}}$ & 0.01 & $0.33^{\mathrm{d}}$ & 0.01 \\
\hline $18: 3 n-3$ & $7.39^{\mathrm{a}}$ & 0.93 & $5.78^{\mathrm{ab}}$ & 0.45 & $4.74^{b c}$ & 0.12 & $3.61^{\mathrm{c}}$ & 0.13 \\
\hline $18: 4 n-3$ & 0.82 & 0.02 & 0.76 & 0.30 & 0.97 & 0.07 & 0.90 & 0.34 \\
\hline $20: 0$ & 0.19 & 0.01 & 0.19 & 0.01 & 0.18 & 0.01 & 0.20 & 0.02 \\
\hline $20: 1 \mathrm{n}-7$ & $0.15^{\mathrm{a}}$ & 0.01 & $0.17^{\mathrm{ab}}$ & 0.01 & $0.18^{b}$ & 0.01 & $0.19^{\mathrm{b}}$ & 0.01 \\
\hline $20: 1 n-9$ & $1.02^{\mathrm{a}}$ & 0.05 & $1.11^{\mathrm{b}}$ & 0.09 & $1.14^{\mathrm{b}}$ & 0.05 & $1.11^{\mathrm{b}}$ & 0.04 \\
\hline 20:1 n-11 & 0.20 & 0.02 & 0.21 & 0.01 & 0.22 & 0.03 & 0.22 & 0.02 \\
\hline $20: 2$ n-6 & 0.28 & 0.06 & 0.32 & 0.03 & 0.29 & 0.04 & 0.25 & 0.07 \\
\hline $20: 3 n-6$ & 0.23 & 0.04 & 0.24 & 0.03 & 0.24 & 0.03 & 0.24 & 0.03 \\
\hline $20: 3 n-3$ & $0.23^{\mathrm{a}}$ & 0.09 & $0.22^{\mathrm{a}}$ & 0.13 & $0.15^{b}$ & 0.01 & $0.17^{\mathrm{b}}$ & 0.13 \\
\hline $20: 4 n-6$ & 0.40 & 0.12 & 0.43 & 0.11 & 0.47 & 0.03 & 0.46 & 0.11 \\
\hline $20: 4 n-3$ & 0.51 & 0.03 & 0.55 & 0.03 & 0.58 & 0.03 & 0.55 & 0.02 \\
\hline $20: 5 n-3$ & $5.57^{\mathrm{a}}$ & 0.39 & $6.06^{\mathrm{a}}$ & 0.52 & $6.83^{b}$ & 0.31 & $6.91^{\mathrm{b}}$ & 0.22 \\
\hline $22: 0$ & 0.16 & 0.06 & 0.14 & 0.03 & 0.13 & 0.05 & 0.17 & 0.07 \\
\hline $22: 1 \mathrm{n}-9$ & 0.31 & 0.02 & 0.30 & 0.01 & 0.31 & 0.03 & 0.30 & 0.01 \\
\hline $22: 1 n-11$ & $0.72^{\mathrm{a}}$ & 0.05 & $0.77^{\mathrm{ab}}$ & 0.03 & $0.80^{\mathrm{b}}$ & 0.05 & $0.80^{\mathrm{b}}$ & 0.02 \\
\hline $22: 5 n-3$ & 1.92 & 0.12 & 2.10 & 0.09 & 2.20 & 0.20 & 2.16 & 0.11 \\
\hline $22: 6 n-3$ & 3.92 & 0.21 & 4.08 & 0.41 & 4.08 & 0.28 & 4.19 & 0.21 \\
\hline $24: 1 \mathrm{n}-9$ & 0.31 & 0.03 & 0.33 & 0.03 & 0.32 & 0.04 & 0.30 & 0.02 \\
\hline Saturates & $26.47^{\mathrm{a}}$ & 1.64 & $27.34^{\mathrm{a}}$ & 0.19 & $27.89^{\mathrm{ab}}$ & 0.88 & $29.03^{b}$ & 0.46 \\
\hline Monoenes & 34.45 & 1.81 & 34.72 & 1.11 & 34.71 & 0.79 & 34.67 & 0.86 \\
\hline n-3 LC-PUFA ${ }^{1}$ & $12.15^{\mathrm{a}}$ & 0.84 & $13.00^{\mathrm{ab}}$ & 0.83 & $13.85^{\mathrm{ab}}$ & 0.65 & $13.97^{\mathrm{b}}$ & 0.46 \\
\hline n-6 LC-PUFA ${ }^{2}$ & 0.92 & 0.22 & 0.99 & 0.10 & 1.01 & 0.05 & 0.95 & 0.11 \\
\hline
\end{tabular}

${ }^{1}$ Calculated excluding 18 C. ${ }^{2}$ Calculated excluding $18 \mathrm{C}$. 
572 Table 5. Effects of finishing diet on fillet weight, wet lipid content and FA profile (\% of total

573 FAME) in fish fed 66VO diet and then FO diet (66VO/FO group). Fish were sequentially

574 sampled through the finishing period (June, +0; July, +27; August, +55; September, +88).

575 Mean values and standard deviations of individual fish are presented $(\mathrm{n}=8)$. Raw values with

576 unlike superscript letters are significantly different over sampling time $(\mathrm{P}<0.05)$.

577

\begin{tabular}{|c|c|c|c|c|c|c|c|c|}
\hline & \multicolumn{2}{|c|}{ Jun $(+0)$} & \multicolumn{2}{|c|}{ Jul $(+27)$} & \multicolumn{2}{|c|}{$\operatorname{Aug}(+55)$} & \multicolumn{2}{|c|}{$\operatorname{Sep}(+88)$} \\
\hline & Mean & SD & Mean & SD & Mean & SD & Mean & SD \\
\hline Fillet (g) & $58.23^{\mathrm{a}}$ & 13.2 & $71.61^{b}$ & 11.1 & $97.65^{\mathrm{c}}$ & 9.33 & $116.2^{\mathrm{d}}$ & 12.9 \\
\hline Lipid (\%) & 9.33 & 2.02 & 10.30 & 3.27 & 11.81 & 2.51 & 11.15 & 1.11 \\
\hline$\Sigma$ FAs $(\mathrm{mg} / \mathrm{g})$ & 59.76 & 14.2 & 56.27 & 20.6 & 67.46 & 17.6 & 55.14 & 7.23 \\
\hline FA $(\%)$ & & & & & & & & \\
\hline $14: 0$ & $2.78^{\mathrm{a}}$ & 0.32 & $3.27^{\mathrm{a}}$ & 0.34 & $3.68^{\mathrm{ab}}$ & 0.27 & $4.38^{\mathrm{b}}$ & 0.39 \\
\hline $15: 0$ & 0.27 & 0.22 & 0.10 & 0.06 & 0.18 & 0.09 & 0.16 & 0.09 \\
\hline $16: 0$ & $16.58^{\mathrm{a}}$ & 0.36 & $17.63^{\mathrm{b}}$ & 0.62 & $18.14^{\mathrm{b}}$ & 0.54 & $18.81^{\mathrm{c}}$ & 0.61 \\
\hline $16: 1 n-7$ & $3.85^{\mathrm{a}}$ & 0.14 & $4.81^{\mathrm{ab}}$ & 0.31 & $5.60^{\mathrm{bc}}$ & 0.19 & $6.20^{c}$ & 0.13 \\
\hline $16: 2$ & $0.27^{\mathrm{a}}$ & 0.09 & $0.39^{\mathrm{ab}}$ & 0.11 & $0.55^{\mathrm{b}}$ & 0.20 & $0.59^{\mathrm{b}}$ & 0.19 \\
\hline $16: 3$ & $0.43^{\mathrm{a}}$ & 0.23 & $0.63^{\mathrm{a}}$ & 0.09 & $0.70^{\mathrm{ab}}$ & 0.21 & $0.91^{\mathrm{b}}$ & 0.07 \\
\hline $16: 4$ & $0.24^{\mathrm{a}}$ & 0.02 & $0.31^{\mathrm{ab}}$ & 0.15 & $0.50^{\mathrm{bc}}$ & 0.05 & $0.60^{\mathrm{c}}$ & 0.08 \\
\hline $17: 0$ & 0.25 & 0.09 & 0.28 & 0.17 & 0.28 & 0.12 & 0.34 & 0.20 \\
\hline 18:0 & 3.85 & 0.12 & 3.86 & 0.18 & 3.81 & 0.13 & 3.85 & 0.21 \\
\hline $18: 1 \mathrm{n}-9$ & $27.06^{\mathrm{a}}$ & 0.71 & $25.89^{\mathrm{b}}$ & 1.43 & $24.62^{\mathrm{c}}$ & 0.58 & $22.80^{\mathrm{d}}$ & 0.90 \\
\hline $18: 1 \mathrm{n}-7$ & $2.00^{\mathrm{a}}$ & 0.12 & $2.31^{\mathrm{b}}$ & 0.11 & $2.46^{\mathrm{c}}$ & 0.16 & $2.66^{\mathrm{d}}$ & 0.09 \\
\hline $18: 2 n-6$ & $15.02^{\mathrm{a}}$ & 0.31 & $13.81^{\mathrm{b}}$ & 0.48 & $12.67^{\mathrm{c}}$ & 0.31 & $11.69^{\mathrm{d}}$ & 0.34 \\
\hline $18: 3 n-6$ & $0.14^{\mathrm{a}}$ & 0.01 & $0.20^{\mathrm{ab}}$ & 0.02 & $0.23^{b c}$ & 0.01 & $0.27^{\mathrm{c}}$ & 0.02 \\
\hline $18: 3 n-3$ & $12.94^{\mathrm{a}}$ & 0.33 & $10.35^{\mathrm{b}}$ & 0.47 & $8.36^{\mathrm{c}}$ & 0.45 & $6.31^{\mathrm{d}}$ & 0.50 \\
\hline $18: 4 n-3$ & $0.60^{\mathrm{a}}$ & 0.06 & $0.61^{\mathrm{ab}}$ & 0.23 & $0.83^{\mathrm{b}}$ & 0.03 & $0.92^{c}$ & 0.07 \\
\hline $20: 0$ & 0.18 & 0.02 & 0.19 & 0.02 & 0.18 & 0.00 & 0.20 & 0.02 \\
\hline $20: 1 n-7$ & $0.11^{\mathrm{a}}$ & 0.01 & $0.13^{\mathrm{bc}}$ & 0.01 & $0.14^{\mathrm{c}}$ & 0.01 & $0.17^{\mathrm{d}}$ & 0.01 \\
\hline $20: 1 n-9$ & $0.96^{\mathrm{a}}$ & 0.03 & $1.00^{\mathrm{ab}}$ & 0.06 & $1.05^{\mathrm{bc}}$ & 0.03 & $1.08^{\mathrm{c}}$ & 0.06 \\
\hline $20: 1 n-11$ & 0.17 & 0.02 & 0.20 & 0.02 & 0.18 & 0.02 & 0.20 & 0.02 \\
\hline $20: 2$ n-6 & 0.32 & 0.07 & 0.30 & 0.13 & 0.24 & 0.09 & 0.30 & 0.04 \\
\hline $20: 3 n-6$ & 0.24 & 0.11 & 0.25 & 0.06 & 0.22 & 0.04 & 0.24 & 0.05 \\
\hline $20: 3 n-3$ & $0.34^{\mathrm{a}}$ & 0.04 & $0.30^{\mathrm{ab}}$ & 0.03 & $0.26^{\mathrm{ab}}$ & 0.05 & $0.24^{\mathrm{b}}$ & 0.09 \\
\hline $20: 4 n-6$ & $0.23^{\mathrm{a}}$ & 0.03 & $0.32^{\mathrm{ab}}$ & 0.10 & $0.33^{\mathrm{ab}}$ & 0.06 & $0.39^{\mathrm{b}}$ & 0.08 \\
\hline $20: 4 n-3$ & $0.42^{\mathrm{a}}$ & 0.02 & $0.47^{\mathrm{b}}$ & 0.06 & $0.49^{\mathrm{bc}}$ & 0.02 & $0.52^{c}$ & 0.02 \\
\hline $20: 5 n-3$ & $2.88^{\mathrm{a}}$ & 0.18 & $3.90^{\mathrm{b}}$ & 0.61 & $5.01^{\mathrm{c}}$ & 0.22 & $5.86^{\mathrm{d}}$ & 0.31 \\
\hline $22: 0$ & 0.14 & 0.03 & 0.17 & 0.06 & 0.13 & 0.04 & 0.18 & 0.04 \\
\hline $22: 1 \mathrm{n}-9$ & 0.29 & 0.01 & 0.30 & 0.02 & 0.29 & 0.01 & 0.30 & 0.02 \\
\hline $22: 1 \mathrm{n}-11$ & $0.58^{\mathrm{a}}$ & 0.01 & $0.65^{\mathrm{b}}$ & 0.03 & $0.69^{c}$ & 0.03 & $0.76^{\mathrm{d}}$ & 0.03 \\
\hline $22: 5 n-3$ & $1.19^{\mathrm{a}}$ & 0.04 & $1.40^{\mathrm{b}}$ & 0.09 & $1.61^{\mathrm{c}}$ & 0.06 & $1.87^{\mathrm{d}}$ & 0.11 \\
\hline $22: 6 n-3$ & $2.57^{\mathrm{a}}$ & 0.21 & $3.14^{\mathrm{b}}$ & 0.38 & $3.28^{\mathrm{b}}$ & 0.26 & $3.65^{c}$ & 0.42 \\
\hline $24: 1 \mathrm{n}-9$ & 0.31 & 0.04 & 0.33 & 0.03 & 0.32 & 0.04 & 0.32 & 0.03 \\
\hline Saturates & $24.04^{\mathrm{a}}$ & 0.67 & $25.50^{\mathrm{b}}$ & 1.10 & $26.39^{\mathrm{b}}$ & 0.74 & $27.92^{\mathrm{b}}$ & 0.92 \\
\hline Monoenes & 35.18 & 0.84 & 35.50 & 1.66 & 35.29 & 0.46 & 34.47 & 0.86 \\
\hline n-3 LC-PUFA ${ }^{1}$ & $7.40^{\mathrm{a}}$ & 0.22 & $9.21^{\mathrm{b}}$ & 0.65 & $10.65^{\mathrm{c}}$ & 0.47 & $12.13^{\mathrm{d}}$ & 0.75 \\
\hline n-6 LC-PUFA ${ }^{2}$ & 0.79 & 0.06 & 0.86 & 0.18 & 0.80 & 0.09 & 0.93 & 0.09 \\
\hline
\end{tabular}

${ }^{1}$ Calculated excluding $18 \mathrm{C} .{ }^{2}$ Calculated excluding $18 \mathrm{C}$. 
$578 \quad$ Figure 1
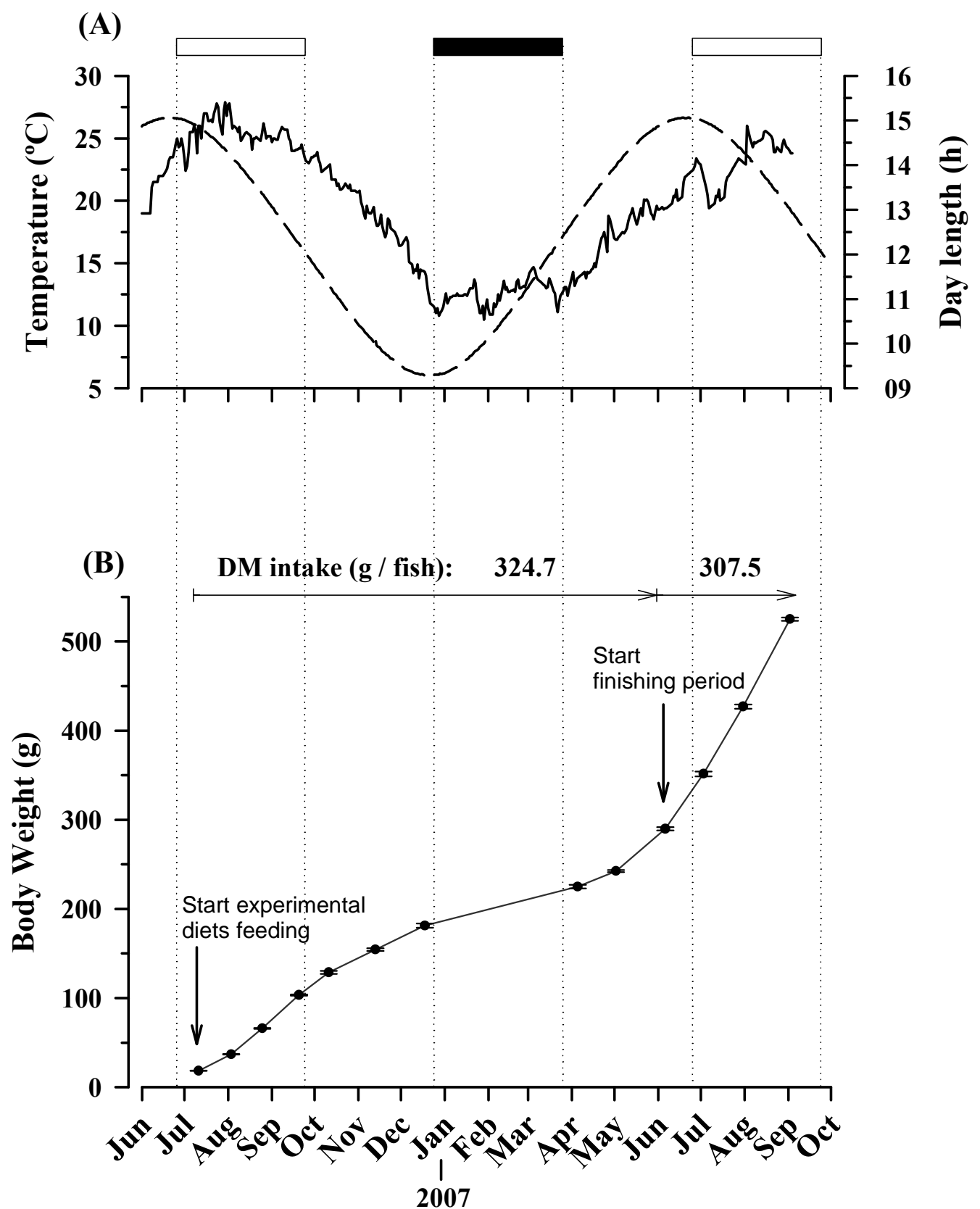
$579 \quad$ Figure 2

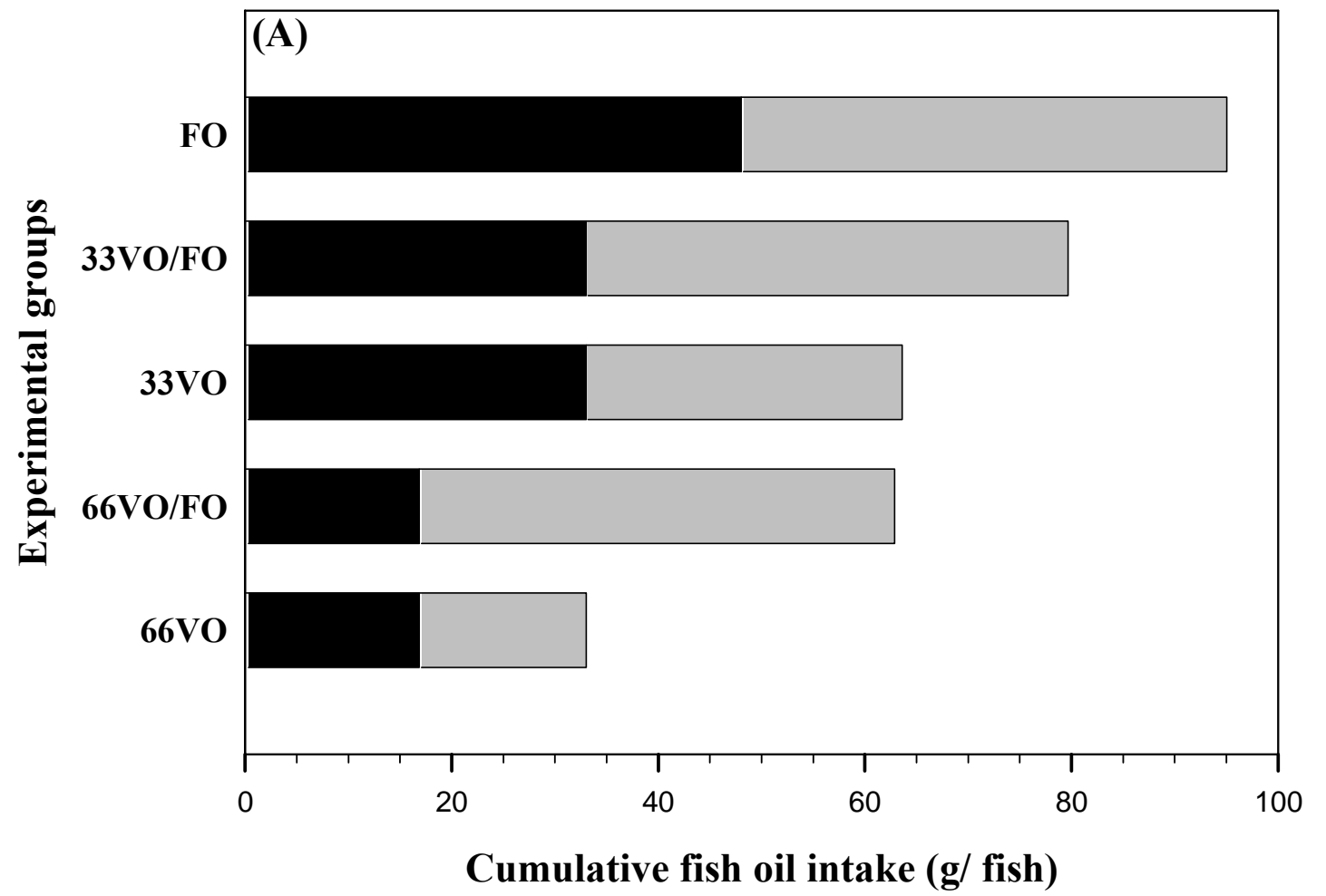


$581 \quad$ Figure 3

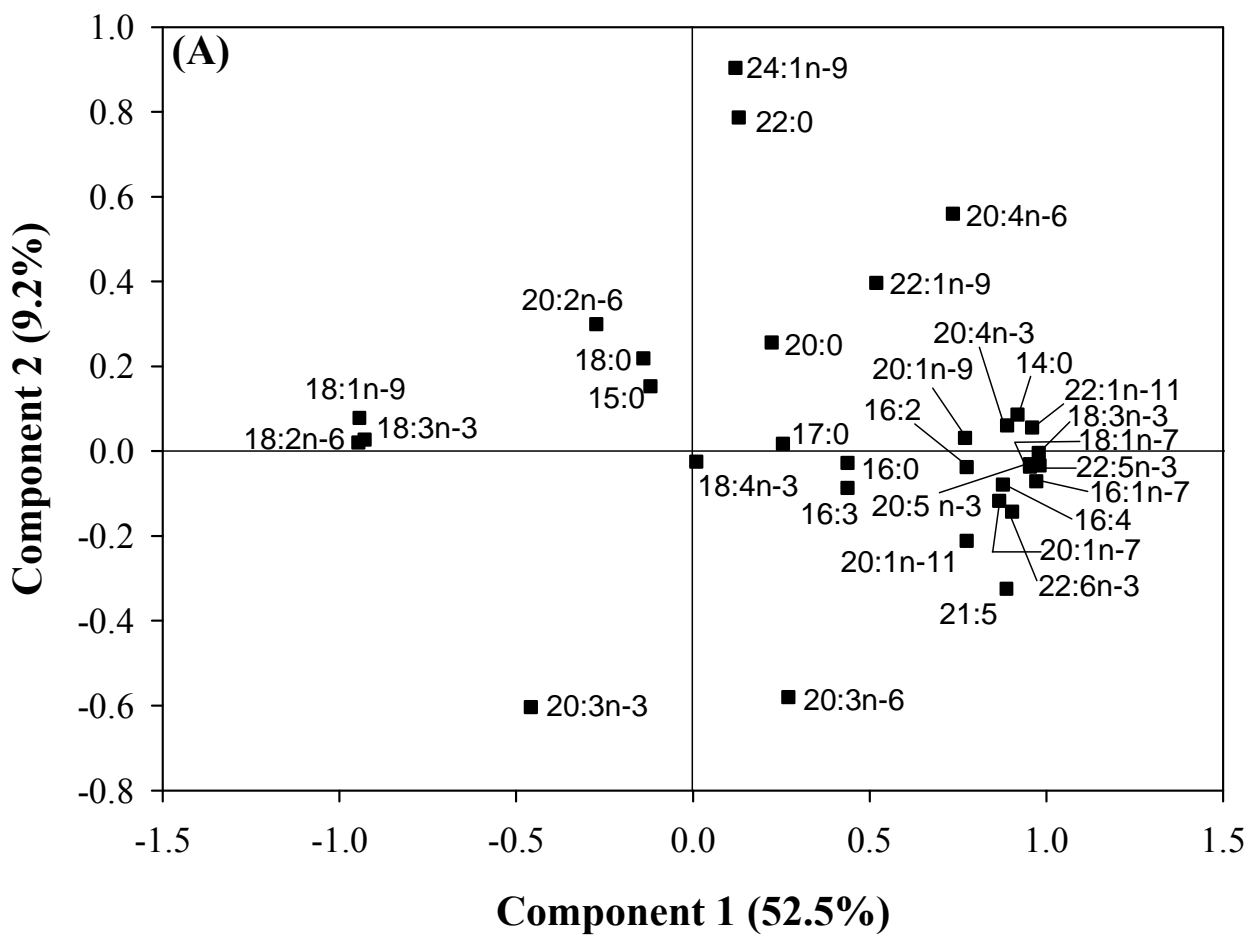

582

(B)

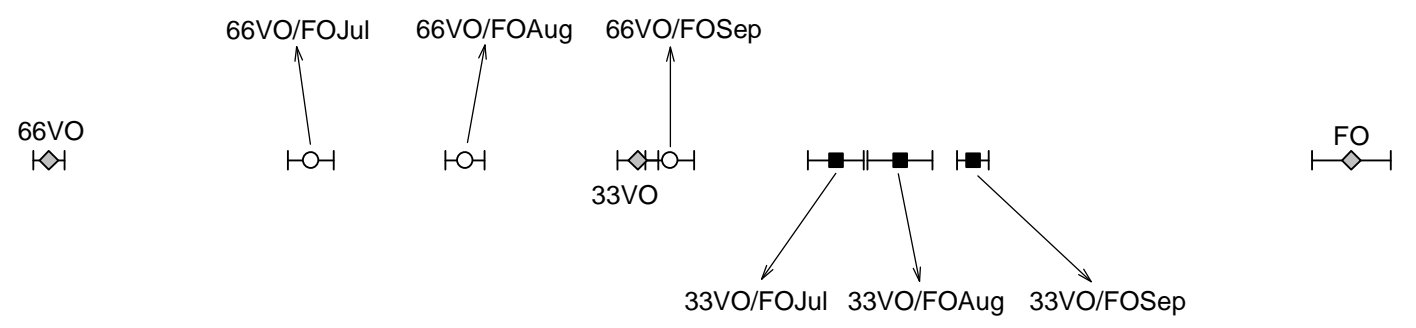

$\begin{array}{llll}-2.0 & -1.5 & -1.0 & -0.5\end{array}$

\section{Factor score plot 1}


$583 \quad$ Figure 4
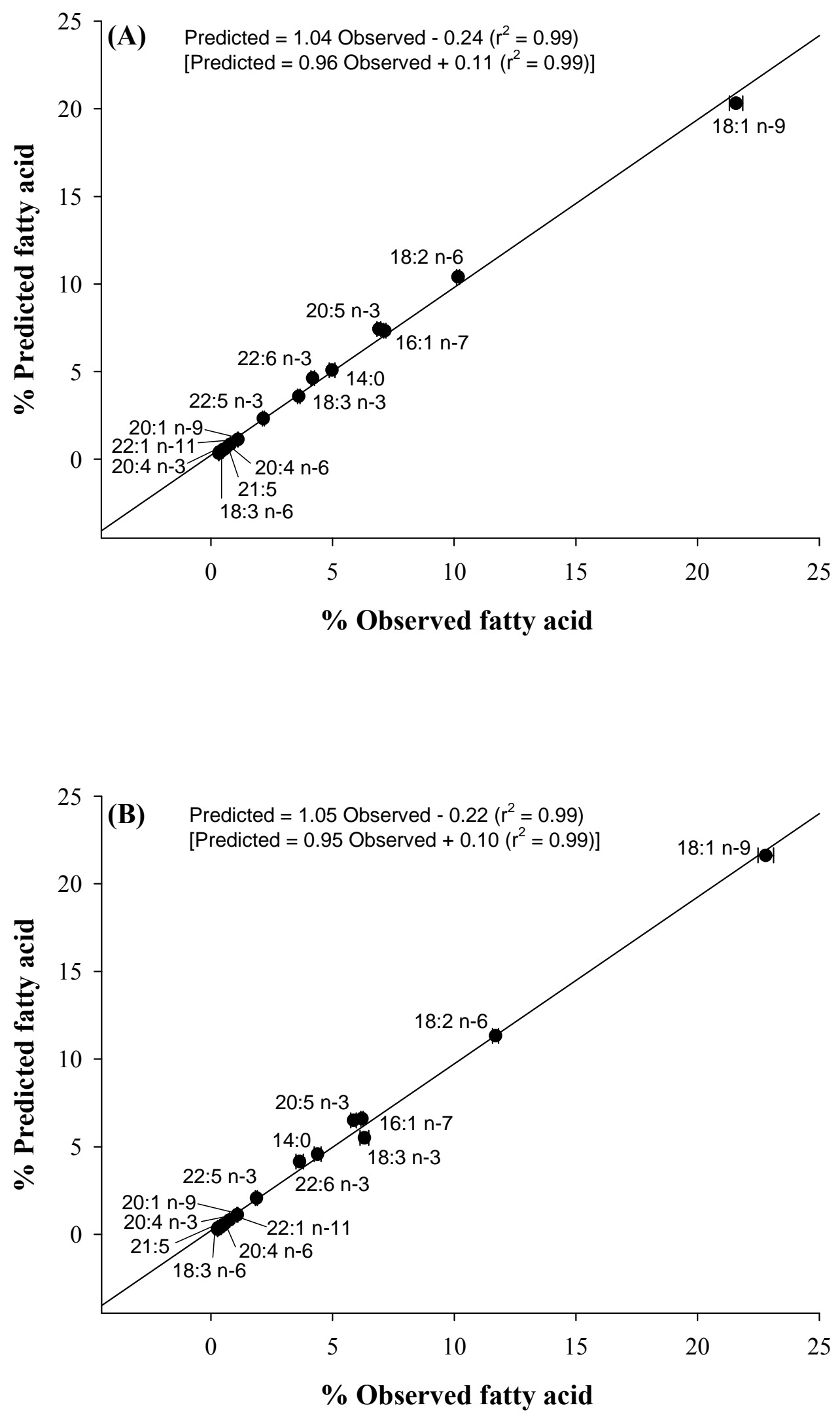